


\section{A écfrase}

\section{a serviço \\ FILHO é professor \\ de Estética do \\ Departamento de \\ Filosofia da PUC-SP.}

OSVALDO FONTES

do auto-retrato

em A Idade Viril,

de Michel Leiris

"[...] sonho que se dá em leitura ou leitura que se impõe com a força de um sonho; cambiante combinação formal agindo como um arco sobre nossas fibras profundas; prelúdio a uma delirante explosão, o ato idolátrico onde cada um dos amantes aponta seu ser inteiro para se tornar estátua sensível e sensibilizante" (Michel Leiris, Frêle Bruit). 
Desde Montaigne, não surpreende que o ato de se dar a si como matéria de um livro exija que defeitos e imperfeições falem tanto quanto as qualidades. É o caso da autobiografia de Michel Leiris (1901-90), que se constrói em torno da autoproclamada mediocridade de seu autor. De fato, o retrato leirisiano abre-se com uma descrição, de tantas outras de um texto particularmente imagético, em que os lineamentos do corpo próprio, de relance refletidos num espelho, diferem da norma por falta ou por excesso:

"Fisicamente, sou de porte médio, mais pequeno que médio [...]. Minha cabeça é um tanto grande para o meu corpo; tenho as pernas um pouco curtas em relação ao torso, os ombros demasiado estreitos em relação aos quadris [...], meu peito é muito largo e a musculatura, pouco desenvolvida" (Leiris, 2003, pp. 27-8).

Aquele que arremata seu retrato lembrando quão necessário é "construir um muro ao redor de si, com o auxílio da roupa" (Leiris, 2003, p. 192), não pode se confortar com suas "disposições médias". A linha de uma "nuca muito reta, caindo verticalmente como uma muralha ou uma falésia" (Leiris, 2003, p. 27), é marca de profunda deselegância mas, sobretudo, signo inquietante de um falseável hieratismo: não podendo ser aquele do dândi, Adão divinamente geométrico cujo rosto empoado aspira à impassibilidade das estátuas de gesso para fugir do "esboroamento" que sente ameaçálo (Leiris, 2003, p. 171), o hieratismo do antivitruviano Leiris é o do insignificante, incapaz de multiplicar perspectivas de si. autobiografia propõe. Esta o faz num duplo processo: por um lado, ela opacifica o óbvio, inscreve-o numa rede de relações de um hermetismo bem ao gosto do autor; por outro lado, ela intensifica o obscuro, fantasmas e lubricidades, emblematizando-o no alegórico, tarefa para a exuberância ecfrástica do texto. Ambas as operações são o modo pelo qual aquele que se diz "o atormentado" procura obter para si uma perspectiva (uma "moldura"), modo de ele se debater com seu "atroz sentimento de impotência, tanto genital quanto intelectual" (Leiris, 2003, p. 183). Assim se espelha a obra, e assim se produz seu imaginário, se não sua fantasmagoria. O corpus textual presta-se a recompor os atributos - forçando-os, por vezes, a vir ter com jogos de fachada -, a viver o destino de homem com a ajuda das palavras (Leiris, 2003, p. 170).

A estética leirisiana, explicitamente tributária da visão da "literatura considerada como uma tauromaquia”, evoca inequivocamente uma economia da torção. As inflexões do matador revelam que a arte não é senão "uma proliferação barroca sobre as duras arestas da vida" (Leiris, 1992, p. 587). O que seduz Leiris nas corridas não é o antagonismo evidente entre a ordem protocolar do toureiro e a desordem natural do animal, mas o modo como se insinuam uma à outrae, sobretudo, a "entorse" que o matador aceita impor a sua retidão para evitar ser levado pelas sinuosidades do touro. Como se, para não morrer, o mais clássico dos toureiros, o mais avaro em floreios tivesse de aceitar por um momento se dar a torneamentos. A “beleza tauromáquica” está nessa infração à geometria, infinitesimal inflexão do corpo, não mais que um ligeiro movimento sincopado que leva, por um instante, o ser inteiro à beira do desequilíbrio (Hollier, 1981, p. 193).

Leiris, sabe-se, cultiva em sua obra o registro dos "sobressaltos, tropeços ou deslizes de pensamento [...], perdas de pé ou saltos de nível” (apud Hollier, 1981, p. 199) ${ }^{1}$. Isso o leva a justificar a literatura na medida em que esta incorre num risco direto para seu autor, põe em jogo sua vida. Além do que, a escrita deve ser capaz de 
suscitar, "preto no branco", uma presença sui generis: presença na iminência de se ausentar. Na última obra, Le Ruban au cou d'Olympia, essa escrita interroga com gravidade tal compromisso:

"[...] como passar, em torno do pescoço das coisas, o laço que as tornará, para mim, como para aqueles a quem delas falarei, tão presentes, insistentes, quanto a Olympia de Manet com seu pescoço riscado de preto? Precioso laço que, esquecendo que é apenas um adereço enfeitado com um nó, do tipo laço de sapato, gostaria de poder usar à vontade e dele fazer - salvaguarda contra o afogamento - a fina mas obsequiosa cinta que seu abraço circular sugere... Laço, todavia, que, ao exame mais honesto de sua imagem pintada - ligadura estreita cerrando um pescoço bem plantado sobre os ombros -, eu deveria antes classificar na mesma tenebrosa família que o garrote do supliciado ou a corda para se enforcar!" (Leiris, 1981, p. 262).

Poder-se-ia estimar que esse laço literário, com o qual o autor confia se assegurar da presença de si e das coisas, joga com o inevitável risco de a presença tão pronto apreendida mostrar-se, por assim dizer, estrangulada. Considerando a totalidade da obra de Leiris - laço de escrita, interminável nó, que se enreda em torno do vocábulo “eu” para agarrar-lhe em armadilha o inefável (Leiris, 1981, p. 268) -, cumpriria mesmo perguntar se, no fim das contas, não seria propriamente esse risco que suscitaria a presença sobre a qual ela pesa: presença na iminência de se ausentar. À evidência, o seu é um laço retorcido, astuto em seus enredamentos, artificioso: ornamento que por vezes deve perder sua inocência decorativa para vir se manifestar nas regiões mais sinistras do garrote do supliciado ou da corda do enforcado.

É sobretudo uma norma de estética que aqui se impõe: a arte é ato de engajamento daquele que, por desejo ou sina, sente-se posto por ela num arriscado jogo confessional. Nisso, é exigido do escritor que saiba introduzir em sua obra "um equivalente do que é para o torero o chifre acerado do touro" (Leiris, 2003, p. 16). Ou seja, que ela reproduza das corridas a saga do Herói por um fio, "o sentimento de uma catástrofe perpetuamente roçada e recomeçada", e a conseqüente "vertigem no seio da qual horrore prazer coincidem” (Leiris, 2003,p. 70). Assim, através do ato literário, aquele que experimenta uma pena enorme a se colocarà altura das coisas tem a possibilidade de olhar de frente a condição humana, de "agarrá-la pelos chifres" (Leiris, 2003, p. 24).

Contudo, se A Idade Viril é um olhar sem complacência dirigido sobre si, o que faz do autor principal testemunha de acusação contra si mesmo - ele que entende "dizer toda a verdade, nada mais que a verdade", sem "floreios” (Leiris, 2003, p. 19) -, tal não se dá "sem um pouco de duplicidade", sem um quinhão de "sagacidade técnica", modo de compensar a própria mediocridade, e "de limitar o escândalo [da confissão] dando-lhe forma estética" (Leiris, 2003, p. 18). O laço da escrita, embora aspire à exatidão realista e à compacidade, não deixa de ser seduzido pelas eventualidades da analogia (Leiris, 1992, p. 285). Com o que fazer figurar forçosamente a lição de um barroquismo tauromáquico: "[...] adjunções decorativas ao que é estritamente exigido pelas necessidades do combate" (Leiris, 1992, p. 587). Afinal, a vida que se espelha na "perturbação" engendrada pelas corridas, misto de "sagrado" e "emoção sexual", entende "que as questões de etiqueta, de estilo, prevalecem sobre a imediata eficácia” (Leiris, 2003, p. 71).

É com estilo, sob o álibi da lucidez e da sinceridade, que se resgata da "desagregação" dos traços, da "degradação do absoluto", da "progressiva degenerescência” em que se traduz "a passagem da juventude à idade madura" (Leiris, 2003, pp. 30-1). A partir de uma profusão de imagens, Leiris propõe se retorcer diante do espelho da literatura. Em outras palavras, em A Idade Viril trata-se de dotaro infame corpo de uma alma e a alma conturbada de um glorioso corpo. Para tanto, cumpre multiplicar e recompor os signos que de antemão parecem unívocos, no limite da insignificância: a 
2 A ausência de continuidade narrativa em A ldade Viril, fato de não se apresentar como uma história sistemática da pe sonalidade de seu autor, justifica que se preferirá falar aqui de "auto-retrato" mais que de "autobiografia". Como salienta Michel Beaujour (1980, p. 30) "é preciso ver no auto-retrato um espelho do EU respondendo en abismo aos grandes espelhos enciclopédicos do mundo". Assim, enquanto na narrativa lauto|biográfica é o processo temporal que domina, oespelh regido por uma metáfora espacial: "[...] ele faz o leito percorrer, seguindo uma ordem que não é necessariament aquela das subdivisões do livro, os compartimentos de um 'espaço' ou de uma tópica" (Beaujour, 1980 , p. 31). Exemplar da tópica leirisiana, seguinte passagem: "Eu poderia comparar o que representa a meus olhos essa galeria de lembranças com o que era para mim, antes de completar sete anos, o rosário que pendia à cabeceira do meu leito: mundo resumido em dezena lcom um grão maior separando as dezenas e uma cruz na ponta e capaz de caber em minha mão; ou, ainda, a natureza vegetal contida por inteiro /sob a forma de ervilhas-de-cheiro capuchinhas, ervas-bezerras no pequeno jardim que, no campo, eu me entretinha então em cultivar; ou também ainda o sinal estranho que eu ficava maravilhado de descobrir no corte dos caules de filifolha e que me parecia - verdadeiro selo de Salomão - condensa todo o meu universo" "Leiris, 2003, p. 40|. Reter-se-á, ainda não sem algum estranhamento, 0 parágrafo inicial de Frêle Bruit. "Mais que seqüência lógica ou cronológica, estas páginas serão-quando acabadasoude fora interrompidas - arquipélago ou constelação, imagem do sa pico de sangue, deflagração de matéria cinzenta ou último vômito com que meu desabamento marcará o céu ficticiamente (Leiris, 1976, p. 7)

Lê-se, ainda, na primeira ficção autobiográfica de Leiris, Aurora (1927-28): "[...] a mim é sempre mais penoso que a quem quer que seja de me exprimir de outro modo que não pelo pronome EU. não que seja preciso ver aí algum sinal particular de meu orgulho, mas porque essa palavra EU resume para mim a estrutura do mundo. As coisas somente são em função de mim mesmo e porque me obrigo conceder alguma atenção sua existência" lapud Beaujour, 1980 , p. 30) aparência, os hábitos, as relações pessoais. E dotá-los de ressonância simbólica por um "jogo de transposições", modo de induzir o metafórico ao que é banalidade demasiado legível. Complementarmente, cumpre absorver os sentidos flutuantes da subjetividade, o inconsciente e a memória, num alegórico de amplo espectro, de modo a ali condensar as relações obscuras do erotismo, da morte e da castração, a favor de uma mitologia pessoal.

A experiência inicial daquele que procura "distinguir com o máximo de pureza [seus] traços" (Leiris, 2003, p. 17) é paradoxalmente a de uma ausência a si; algo se furta, e deve ser hipostasiado no papel. Para tanto, a escrita alinha sonhos, fantasmas e lembranças, todo um "material sedutor" de fatos e imagens é condensado "no estado quase bruto" (Leiris, 2003, p. 19), de modo a constituir um vasto corpus, sucedâneo à "feiúra humilhante" que o olhar surpreende no espelho. Nesse inventário de elementos heteróclitos, solidário de uma mimese do eu, "amplo crédito" é concedido à psicologia freudiana, na medida em que ela confirma para o autor o hábito de "proceder por alusões, por metáforas" e de "pensar por formas, analogias, enigmas", o gosto por um certo hermetismo e o amor antigo pelas alegorias. Na verdade, a psicanálise fornece para Leiris uma espécie de caução científica à "colagem surrealista" e à "fotomontagem" que o texto investe e donde ele afirma retirar sua "autenticidade" (Leiris, 2003, p. 54). Mesmo porque a narrativa, em que a continuidade da ordem cronológica perde relevância para a descontinuidade dos jogos de analogia e de associação ${ }^{2}$, entende constituir particular taxinomia dos movimentos anímicos.

Não surpreende, pois, que o auto-retrato se conceba como o microcosmo, escrito na primeira pessoa, de um percurso enciclopédico; como uma tomada de consciência textual das interferências e homologias entre o Eu singular e o Espelho geral da Cultura. O discurso sobre o espaço íntimo não escamoteia seu anseio de refletir o discurso coletivo sobre o universo. Mas imaginar, ali, não é tanto participar do mundo quanto obsedar a própria imagem sob as aparências infinitamente variáveis de que ela, reflexo indefinível nos grandes espelhos enciclopédicos, pode se revestir (Beaujour, 1980, p. 30). Exemplar, a propósito, o que se lê em Biffures (1948), primeiro tomo de um ciclo intitulado A Regra do Jogo que, por trinta e cinco anos, perseverou na colagem de dados da vida íntima inaugurada por $A$ Idade Viril:

"Constato que um único desígnio foi para mim permanente: operar uma mise en présence, traçar pistas ligando entre si elementos. Satisfação em reunir, cimentar, enlaçar, fazer convergir, como se se tratasse - qualquer que fosse o modo de meu esforço se aplicar e quaisquer que fossem os meus materiais originais - de agrupar num mesmo quadro todo tipo de dados heteróclitos relativos a minha pessoa para obter um livroque seja, finalmente, em relação a mim mesmo, um compêndio de enciclopédia comparável ao que eram outrora, quanto ao inventário do mundo em que vivemos, certos almanaques (tal como aquele das edições Hachette: uma mina de ensinamentos variados, sob cobertura ornada de um austero perfil laureado) ou então o Memento de bolso elaborado pela Larousse para uso dos candidatos ao certificado de estudos primários, volume de dimensões reduzidas (muito mais, certamente, do que arrisca ser este que motiva aqui estas reflexões) e nos quais me parecia, quando era criança, que o essencial dos conhecimentos humanos, em poucas páginas, tinha sido condensado" (Leiris, 1975, p. 285) ${ }^{3}$.

Reunir, relacionar, condensar: tal é o método para tornar presente uma individualidade. A combinatória dos conteúdos de memória, associados a cenas ou quadros, evoca inequivocamente os "lugares" e as “imagens" da memória artificial. Um Eu se preenche de conteúdo mnêmico ao percorrer múltiplos episódios narrativos ou exempla que se encadeiam na sua biografia - numa simbologia eclética, diga-se, indo dos cavaleiros da Távola Redonda aos ícones da história santa, das cenas burlescas do vaudeville aos refinamentos estéticos da grande 
pintura renascentista. Na verdade, A Idade Viril não é obra de memorialista, reconstituição de uma trajetória contínua de vida. O cronológico, como se disse, submete-se ali ao topológico. O espelho de Leiris não faz senão recolher fatos e imagens numa tópica muito particular: a família, o teatro, o bordel; temperada pelo jogo das rubricas: sacrifício, amor, expiação, morte. O que ali "se espelha/se especula" - sobretudo em torno da vacuidade do autor e da procura pela taxinomia de seus lugares-comuns -, não se traduz tanto numa narrativa continuada quanto numa topografia da alma - para não dizer numa mitografia -, e na conseqüente sugestão de transposições entre seus vários lugares. O escritor que se contempla, esclarece Francis Jacques (1982, p. 199), "se esforça por estabelecer entre suas impressões, fluxo de desejo, amores, todos os acontecimentos notáveis vividos in foro interno, uma continuidade de miseen-scène". O auto-retrato é, igualmente, jogo teatral ${ }^{4}$

No trabalho de condensação desses "lugares" da interioridade - no que Leiris diz ser um "plano trágico", aquele da máxima teatralização do $\mathrm{Eu}$-, a escrita autobiográfica aspira à anamnese total, em que as experiências de vida não mais são representadas segundo uma duração, mas como um panorama, uma coexistência, uma justaposição de elementos, enfim, um espaço (Beaujour, 1980, pp. 147-8). Não é, pois, casual que Leiris fale do esforço de "fotomontagem" em A Idade Viril como a tentativa de "concentrar a minha vida num único bloco sólido (objeto que eu poderia tocar como para as segurar-me contra a morte, ainda que, paradoxalmente, pretendesse arriscar tudo)" (Leiris, 2003, p. 23). Mais à frente, lê-se que a confissão, destilando imagens de efeito catártico, entende traduzir um "resumo de memórias, visão panorâmica de todo um aspecto de minha vida" (Leiris, 2003, p. 40). Em registro semelhante, mas com gravidade maior, observa-se a seguinte passagem em Fibrilles (1966), terceiro tomo do extenso repertório autobiográfico de A Regra do Jogo, momento de balanço da língua introspectiva:
“[...] Meu propósito não é aquele de um memorialista pois que eu gostaria, mais que de reconstituir minha vida seguindo-a passo a passo, de dominá-la abraçando-a com um só olhar (um olhar situado no tempo mas já fora do tempo, comparável àquele que se atribui ao homem em vias de se afogar e que revê, em uma piscada, o inteiro desenrolar de sua existência)" (Leiris, 1966, p. 223).

Tal exposição da vida na chave da morte revela-se justa imagem do livro autobiográfico: ela convida o leitor a fazer abstração da duração da leitura de modo a que o livro (o autor) apresente na sua exposição panorâmica e fictícia simultaneidade (Beaujour, 1980, p. 148). Através da condensação da escrita, Leiris aspira a se ver espelhado na eternidade de um instante. Constrangido entre a ausência de que se ressente e a presença a que aspira, o auto-retratado procura produzir, com seu "torneado" literário - que não é senão drama da escrita, escrita que se conta a si mesma -, o que será sempre um entrelace de antropologia e de tanatografia. Mesmo porque o presente de um $\mathrm{Eu}$, a presença a si, que uma interpretação apressada tomaria como o objeto mesmo do auto-retrato, é tão-somente seu engodo ou seu reverso fantasmático. Com razão Michel Beaujour afirma não haver escrita menos inocente, "mais dilacerada e dilacerante", que aquela do auto-retrato (Beaujour, 1980,p. 13). Isso porque nela não há um bios distinto de seu graphein. $\mathrm{O}$ auto-retratista não se antecipa a seu texto. Se ele aspira, como se lê em Biffures, "a praticar sobre [as lembranças] algo equivalente àquela respiração artificial por meio da qual se procura reanimar os afogados" (Leiris, 1975, p. 60), tal exige de si uma morte ao presente. O presente é, antes, aquele da invenção, tempo para se reconhecer os vastos lugares de uma tópica impessoal, anônima, tributária inevitável de uma máquina retórica e que é, no fim das contas, puro discurso ocioso. $\mathrm{O}$ Eu que escreve não é mais que "livro dentre livros" (Beaujour, 1980, p. 13) ${ }^{5}$

Texto de ociosidade, o auto-retrato impacienta-se com sua congênita má consciência:
4 lê-se em Biffures: "Que eu faça a caça ao instante presente que me escapou, a caça à embrança que se desfez em poeira ou a caça àqueles objeos imaginários que parecem se esconder por detrás das falsas anelas de palavras pintadas em trompe-t'oeil sobre a fachada de meu espírito, é sempre a mesma presa que persigo" |Leiris, 1975, p. 23). A interferência entre as metáforas da caça e do teatro sugere uma caça eatral que se põe ela própria em cena: "confissão involuntária de retórica", estima Beaujour $(1980$ p. 250), ela indicia o que no texto autobiográfico é da ordem de um engendramento das fachadas do espírito, de uma falsa similitude.

5 Em Frêle Bruit, texto que fecha em 1976 o ciclo de A Regra do Jogo, Leiris exprime seu receio de ter tomado como im o que pretendera ser um meio, ou seia, "em lugar de escrever minha vida para saber vivê-la melhor", ter feito "como se minha vida tal como a vivi tivesse tendido essencialmente a ser escrita e como se toda a maravilha que pôde esclarecêa tivera por principal efeito a narrativa que dela forneci" (Leiris, 1976, p. 379). 
6 A reconstituição das lembranças de infância, exercício de risco, é mesmo processo dubitativo: "[...] quem me garante", pergunta Leiris, "que não dou a essas lembranças um sentido que elas não tiveram, carregando-as posteriormente de um valor emotivo que não possuíram os acontecimentos reais aos quais elas se referem, em suma, ressuscitando esse passado de uma maneira tendenciosa?" |Leiris, 2003, p. 49). Em outras palavras num espelho de tinta, onde os traços se pretendem finos e certeiros, como assegurar que não se carrega demasiado mente nas tintas? Como evitar que uma autografia degringole do verossímil ao paródico? $\mathrm{O}$ evitar que aquele que entende erguer sua estátua acabe um "idolo risível, nem mesmo bom para um museu Grévin" "Leiris, 1975 , p. 240|?

7 Anteriormente, na mesma análise, Lejeune falara do auto-retrato leirisiano como de "um texto incansável e fascinante [...], imenso maquinário linguageiro tecendo e tramando um discurso que se esforça para preencher aquele vazio donde sai a linguagem, e sem outro fim que a morte" (Lejeune, 1996 p. 247). Mais à frente, Lejeune fala dessa trama textual como do trabalho de construção de um corpus onde "alcança uma experiência total que não tardamos a compreender, seria, ao mesmo tempo que a plena realização da linguagem, seu desaparecimento ou sua dilaceração, isto é, a morte (Lejeune, 1996, p. 250)

8 Lê-se ainda em Biffures: "Se quero dar corpo a esse momento presente - a essa presença mesma - , eis que ele se furta, se vela: e tudo o que pude dize dele-não podendo interpelá-lo diretamente (enquanto gostaria de the berrar... l, tudo o que eu podia inventar para trazê-lo-ou para fazêto retornar - à real dade se mostra um palavrório dos mais inúteis: alinho frases acumulo palavras e figuras de linguagem, mas em cada uma dessas armadilhas o que prendo é sempre a sombra e não a presa" (Lejeune, 1975, pp. 23 4). A metáfora da caça, velha imagem da invenção retórica, trai a idéia de que a escrita é um jogo que pode provoca o mal-estar do jogador. Afinal não é a Verdade seu campo mas o possível e o verossímil (Beaujour, 1980, p. 50). Ou antes, a Mentira, "mulher de sorriso sedutor e suntuosamente enfeitada", motivo de fascinação para Leiris $(2003$, p. 53)

9 "Exorbitado" nãoé, aqui, adjetivo inapropriado para fala do autor de A ldade Virit: sua escrita, envolvida com os tormentos pessoais, permanece estética, anódina, capaz unicamente de "proferir um delicado gemido", inglório em face do "alarido torturado do mundo" (Leiris, 2003, p. 17). Às portas de se arriscar no relato do que deveria manter sob reserva - a morte, a vergonha e o horror associados ao desejo e ao prazer na busca por uma voluptuosa redenção da mediocridade - , Leiris estigmatiza tanto a si quanto a sua obra, desafiada a introduzir "uma grandeza aparente ali onde eu sabia muito bem não haver nenhuma" (Leiris, 2003, p. 18).

Incapaz de fugir aos jogos de espelho da linguagem, essa escrita de ociosidade carrega ainda a inquietação com sua própria organização. Mesmo porque, invariavelmente, esta fraqueja. Comumente, o intento de fixar a intimidade em "artigos de catecismo" vê-se transmudado em "palavrório inútil”" (Leiris, 1966, p. 243)6. Não é raro que Leiris relate a "impressão de fraudar ao escrever essas páginas que não cessam de pretender a total autenticidade" mas que relevam quiçá uma "arbitrariedade".

“À medida que escrevo, o plano que havia traçado me escapa e, quanto mais olho para mim mesmo, tanto mais confuso se torna o que vejo, os temas que eu acreditara primitivamente distinguir revelam-se inconsistentes e arbitrários, como se essa classificação não fosse, afinal de contas, senão uma espécie de planta abstrata, ou mesmo um mero procedimento de composição estética" (Leiris, 2003, p. 120).

No arriscado jogo da confissão, no dubitativo balanço que aí se oferece entre artifícios que se negam como tais e a sinceridade a que se aspira - enfim, entre o lábil da presença e o labor da invenção -, o texto entende manifestar o que palavras e sonhos mantêm na ponta da língua: "a autenticidade", "o avesso das cartas"... "o chifre acerado do touro" (Lejeune, 1996, p. 250). O trabalho da linguagem, exercício in absentia, espera que um acontecimento nasça da escrita, apresente-se por força mesmo dessa escrita. É o que precisamente orienta a confissão em A Idade Viril: que ela revele o fundo à medida que lhe dá forma (Leiris, 2003, p. 24). Se, porém, tudo termina na constatação da futilidade de um jogo linguageiro laborioso, é porque de fato nada advém ao final da linguagem que não esteja impregnado de uma falta (Lejeune, 1996, p. 287) ${ }^{7}$. Em outros termos, o efeito de presença resultaria, segundo a definição que Leiris lhe dá em $O$ Espelho da Tauromaquia, da “gota d'água que faltará sempre para que transborde o vaso" (apud Hollier, 1981 , p. 192) ${ }^{8}$. O intento da expressão autobiográfica não parece ser outro que o de ler essa falta ou ausência na linguagem. “Quero me ver puro” (Leiris, 2003, p. 145): eis todo um programa estético unicamente para aquele que usa uma "máscara ou lentes deformantes", ou que venha consentir em ser exorbitado pelo próprio imaginário 9 .

Antes de nos reportarmos mais detidamente às écfrases do texto de Leiris, não é sem proveito uma observação complementar quanto ao ethos daquele que ali se espelha. A ética do auto-retrato, sabe-se, depende amplamente da arte: é ela que impõe uma disposição às partes do texto e, conseqüientemente, um temperamento aos desejos. Ocorre, porém, de essa ética induzirigualmente o movimento inverso, de subversão do que tenderia a se expor numa ordenação enciclopédica. Assim, a tudo o que estiver de antemão regido pela Temperança, e tender pour cause a fechar retrato e retratado num microcosmo harmonioso, vem se opor a violência de uma escrita intemperante, libidinosa e aberta à morte. "Como enciclopédia, esclarece Roland Barthes, [o auto-retrato moderno] extenua uma lista de objetos heteróclitos, e essa lista é a antiestrutura da obra, sua obscura e louca poligrafia" (apud Beaujour, 1980, p. 36). Virtudes e vícios, que normalmente se combatem nas éticas protocoladas, vêm assim se combinar num Irreconciliável em que se configura um Eu particularmente afeito à impessoalidade moderna: não mais o "eu estruturado do mundo, estima Maurice Blanchot, mas já a estátua monumental, sem olhar, sem figura e sem nome: o ele da morte soberana" (apud Leiris, 1966, p. 6). O Outro 
(a morte, o inominável, o irreconhecível, a mediocridade), ainda que permaneça o fiador do que o escritor reúne e distribui em seu auto-retrato, é fator de todos os riscos - ao patrocinar o antiestrutural. Ali se originam as imagens. Portanto, as contundências. Ali o texto assume plenamente sua vocação ecfrástica.

\section{$\bullet \bullet \bullet$}

Fruto do trabalho de composição textual, de "fotomontagem", para evitar a "progressiva degenerescência" da vida, o imaginário em A Idade Viril parece siderado pelas figuras míticas de Lucrécia e de Judite, símbolos esteticamente balizados da passividade masoquista e da agressividade sádica. Judite e Lucrécia são os pontos da verdadeira agitação alegórica da narrativa, "pólos legendários" em que a "colagem surrealista" de imagens tem seu paroxismo fantasmático. Mesmo porque as pinturas de Lucas Cranach (1472-1553) descritas por Leiris são o lugar evocativo mais propenso a tocar o Eu que se constrói: pelo erotismo "extraordinário" de que estão investidas - a sexualidade sendo "pedra angular do edifício da personalidade" (Leiris, 2003, p. 22) -, por seu caráter antigo, fetiche maior do esteta Leiris, e, sobretudo, por "seu lado profundamente cruel”, propício pois àquele que busca expiação ${ }^{10}$. Enfim, tudo nas duas figuras femininas concorre para tornar sua representação particularmente sugestiva, "o tipo mesmo da pintura diante da qual "perder os sentidos"” (Leiris, 2003, p. 55, tradução modificada).

A imagem diante da qual perder os sentidos é aquela que guarda todos os sentidos. Restituir através dela uma presença, força de evidenciação da écfrase, é restituir a presença daquele que se sente por ela tocado. Para tanto, cumpre ressaltar seu efeito de avanço (prae-sens), que faz de seus espectadores destinatários particularmente pungidos. Ao descrevê-la, seria caso de relevar esse ponto de contato - localizável talvez no que Roland Barthes chamaria o punctum, o que nos punge de uma imagem. Em suma, cumpriria relevar-lhe o aspecto repercussivo, mesmo porque nos dois ícones de Cranach parecem ressoar as vibrações do ethos de Leiris, agitado que é pelo eros da pintura.

A dimensão ostensiva de uma descrição pode ser estimada pelo transporte da imaginação que propicia, através do qual - nas palavras de Louis Marin - uma imagem aparece "insistente, obsessiva, enfeitiçante, invadindo a alma, ocupando o espírito, trabalhando o sentido e os sentidos, pronta para transpor as fronteiras do interior e do exterior, em via de visão ou de alucinação" (Marin, 1993, p. 73) ${ }^{11}$. De fato, no texto leirisiano não parece outro o estatuto das duas figuras de feminilidade antiga (e cruel). "Antigüidade" e "crueldade" são termos afetivamente carregados para Leiris, e portanto possuem uma segura ressonância, isto é, virtudes de associação. Se o trabalho da escrita consiste em aproximare em elaborar relações - por diversas vezes Leiris assim o caracteriza -, entãoé de esperar que na “colagem surrealista" de A Idade Viril o díptico de Cranach ressoe sentidos contundentes. De fato, ao insistir na conjunção LucréciaJudite, Leiris reconhece que em ambas, na casta e na desavergonhada, um mesmo gesto de "lavar no sangue a mancha de uma ação erótica" (Leiris, 2003, p. 133) traduz os sentimentos de tormento, ignomínia e terror a elas associados (Leiris, 2003, p. 188). Uma pelo suicídio, outra pelo assassínio, ambas reproduzem, em imagem, a lição fornecida pela "beleza sobre-humana" da tourada: o sentido trágico do amor, "união e combate ao mesmo tempo" (Leiris, 2003, p. 70). Portanto, deduz Leiris, não terá sido por um simples capricho, mas em virtude de "analogias profundas"- entre terror e santidade, beleza e medo -, que Cranach pintou-as em conjunto, “ambas igualmente nuas e desejáveis, confundidas nessa ausência completa de hierarquia moral que a nudez dos corpos implica" (Leiris, 2003, p. 134).

Eis, então, as duas centrais e magistrais écfrases de A Idade Viril. "Uma frente à outra", como Leiris as anuncia, "as duas grandes nudezas antigas, anjos iguais do Bem e do Mal, situadas, pelo sangue com que estão maculadas, num mesmo plano de texto que faz uso copioso da écfrase-tomada em sua acep ção mais trivial, como descrição estilisticamente depurada de obras de arte, de maneira a evidenciá-las/presentificá-las ele "exorbita" o olhar, retira-o de sua orbitância cotidiana banal, como uma aspiração obtê-lo admirativo, medusado mesmo, até ao paroxismo do "olho vazado" (Leiris, 2003, p. 77).

100 tom de auto-imolação que assumem as confissões de Leiris confirma o que ele diz ser, desde tenra idade, seu "gosto muito pronunciado pelo trágico, pelos amores infelizes, por tudo o que termine de maneira lamentável, na tristeza e no sangue" "Leiris, 2003, p. 46). Para estimá-lo, bastaria quiçá, percorrer alguns títulos de capítulos: "Sacrifícios", "Olhos Vazados", "Garganta Cortada", "Pé Ferido, Nádega Mordida, Corte na Cabeça", "Pontos de Sutura", "O Umbigo Sangrento"

11 Apaixonado pela cena lírica, leiris admira aqueles momentos de puro sortilégio em que a representação "lança uma ponte entre ficção e realidade e suprime, num repente, "toda distância entre o palco e a orquestra, entre a cena e a sala" (Leiris, 1981, p. 18) Em A ldade Viril, ele se mostra impressionado pela representação de uma peça de Molière, em que a linguagem é "língua viva, concreta, cujas palavras transpõem a ribalta, enquanto a ação, em saraivada de golpes faz estremecer o palco" "Leiris, 2003, p. 195). A obediência estrita às normas da arte seriedade por vezes próxima do pedantismo, circunstancialmente cede a uma desenvolta tamiliaridade com o produto cultural de modo a dele obter um "efeito de presença", a fazêto ter a força de um acontecimento, capaz assim de atingir camadas afetivas mais íntimas. Eis o que Leiris parece perseguir ao sobreinvestir afefivamente sua galeria pessoal de imagens e personagens estereotipados. 
matança em que se apaga toda mediocridade" (Leiris, 2003, p. 135).

Primeiramente, Lucrécia, a casta, na iminência de se dar à morte após o ultraje sofrido, começo do fim da realeza em Roma, deixa-se ver:

“[...] apoiando no centro de seu peito branco, entre dois seios maravilhosamente duros e redondos (cujas pontas parecem tão rígidas quanto as pedras que ornam no mesmo sítio um gorjal ou uma couraça), a lâmina afiada de um punhal em cuja ponta pendem já como pérolas, como o dom mais íntimo que surge na extremidade de um sexo, algumas gotas de sangue, e preparando-se para anular o efeito da violação que sofreu com um gesto semelhante; gesto que enfiará numa quente bainha de carne, $\mathrm{e}$ para uma morte sangrenta, a arma esticada ao máximo, como a virilidade inexorável do violador quando entrou à força no orifício já escancarado entre suas coxas, doce fenda rosada que poucos instantes depois restituía a libação a grandes goles, exatamente como a ferida - mais profunda, mais mordaz, mas talvez ainda mais embriagadora - feita pelo punhal que faria brotar, no âmago de Lucrécia desfalecida ou a expirar, um jato de sangue" (Leiris, 2003, p. 134).

A romana Lucrécia é figura feminina particularmente evocativa para aquele que não concebe o amor senão "no tormento e nas lágrimas" (Leiris, 2003, p. 74). Assim, não escapa ao leitor atento que sua descrição é lugar de uma denegação: Lucrécia, na iminência de sua expiação, já estaria morta. Não sem razão Roland Barthes denota que a descrição "se esgota a dar o caráter mortal do objeto, fingindo acreditá-lo, desejá-lo vivo: 'fazer vivo' quer dizer "ver morto", (Barthes, 2003, p. 82). Afinal, uma imagem mediatiza, apresenta, porque metaforiza a ausência, a ela substituindo, ou melhor, acrescentando-lhe com naturalidade um sentimento de iconofilia (Jacques, 1982, p. 197). Pela descrição, Leiris na verdade aspira a ver Lucrécia morta. Desesperadora fragilidade da beleza, presença que não se dá senão no antegosto de seu desaparecimento, Lucrécia é a exemplificação maior da "fragilidade de todos aqueles cuja existência the fala ao coração" (apud Hollier, 1981, p. 198). Notar-se-á com proveito que na versão da pintura de Cranach conservada na Pinacoteca de Dresden, aquela a que faz referência Leiris, Lucrécia porta um fino laço preto delicadamente amarrado a seu pescoço; nó tão ameaçador, se não mais, quanto o espesso colar que lhe complementa o ornamento de condenada pelo destino. Leiris não se ocupa do detalhe do nó no pescoço de Lucrécia, mas ele poderia facilmente vir se acrescentar como marca sensível a uma descrição particularmente pontuada pela imagem da ferida, da penetração. $\mathrm{Na}$ verdade, o que punge Leiris na imagem está ausente: o órgão feminino que, em outro momento do texto, ele compara a uma ferida, "não menos atraente por isso, mas perigosa por si mesma, como tudo o que é sangrento, mucoso, contaminado"... vazado (Leiris, 2003, p. 78).

Em seguida, Judite é descrita. A “desavergonhada patriota", já alheia à violência que a levou a empunhar a cabeça de Holofernes, deixa-se ver:

“[...] tendo à mão direita uma espada nua como ela, cuja ponta fere o solo a pouca distância de seus dedos do pé, e cuja lâmina muito larga e muito sólida acaba de cortar a cabeça de Holofernes, que pende, despojo sinistro, da mão esquerda da heroína, dedos e cabelos misturados numa união atroz; Judite, ornada de um colar tão pesado como um grilhão de condenado, cujo frio em volta do pescoço voluptuoso evoca o da espada junto a seus pés; Judite plácida e parecendo não mais pensar na cabeça barbuda que segura como um botão fálico que tivesse podido cortar, fechando seus lábios inferiores no momento em que as eclusas de Holofernes se abriam, ou então que, ogra em pleno delírio, ela tivesse destacado do grosso membro do homem embriagado (e talvez vomitando) com uma súbita dentada" (Leiris, 2003, p. 134). 
A bíblica Judite é figura particularmente perturbadora por instanciar a rigidez e a fatalidade que acompanham para Leiris a idéia de Antigüidade (Leiris, 2003, p. 79). Sofrimento, fracasso, expiação, castigo: nela, Leiris encontra a "figura em torno da qual cristalizar imagens que tiveram uma influência decisiva em [sua] vida" (Leiris, 2003, p. 87). De fato, todos os mitemas leirisianos aí estão, com a eficácia hermenêutica que se queira atribuir-lhes: o colar-garrote, a impotência mortificada, o erotismo impregnado de tormento, ignomínia, terror. Ainda, quiçá, a "rigidez antiga" matizada racinianamente por uma "penugem de alcova” (Leiris, 2003, p. 65). Aliás, a descrição parece uma vez mais evocar a imaginação: a “imagem insolente" de Judite, que Leiris diz ofuscar aquela de Lucrécia, vai muito além do que a pintura de Cranach nos oferece ${ }^{12}$ - não mais que a oportunidade de explorar a sensualidade da nudez sob os auspícios do mitológico -, e permite as suposições de um olhar transido pela fantasia. Judite deixa-se, pois, imaginar

"[...] tal como deve ter se apresentado ao sair da tenda de Holofernes [...] com suas unhas agudas coloridas pelo assassinato [...], suas roupas amarrotadas cobertas de suor e poeira e vestidas às pressas - na maior desordem -, deixando entrever sua carne ainda lambuzada de dejetos e de sangue" (Leiris, 2003, p. 135).

Nada que corresponda de fato ao que apresenta a refinada figura de Cranach. Está claro que a descrição aciona aqui associações escusas não prescritas nos escolares manuais das belas-artes. E não surpreende que a écfrase termine por instalar o descritor "tal como Holofernes com a cabeça cortada", imaginando-se deitado aos pés desse “ídolo" (Leiris, 2003, p. 135). Lugar por excelência de excitação do olhar, a imagem idolátrica em seu efeito pático convida mesmo ao relato das "várias Judites de carne e osso", mulheres que "me cortam a garganta com seus olhos de Medusa" (Leiris, 2003, p. 139, tradução modificada): imagens perturbadoras, evocadas por eventos da vida do autor marcados pelo medo e pela repugnância extremos. Tendo investido a imaginação, o descritivo intensifica o desejo de ver.

Os "olhos paralisantes de Judite" são o paroxismo da pulsão escópica, o que explica sua ascendência como imagem sobre a "muito doce e pura" Lucrécia, pois que através deles o "tocado" (exorbitado?) Leiris experimenta a violenta subversão de toda relação moralmente protocolada. Judite representa a oportunidade de preservar o amor de sua natural profanação pela posse. Lê-se:

“[...] a única chance prática de salvação é o amor voltado a uma criatura suficientemente singular para que, apesar da incessante aproximação, nunca se atinja o limite do conhecimento que se pode ter dela, ou dotada de uma graça sedutora tão instintiva que, por mais profundamente que nos ame, pareça a todo instante prestes a se evadir" (Leiris, 2003, p. 164).

O que se evade, o que escapa, guarda consigo o caráter trágico do que aterroriza e paralisa (Leiris, 2003, p. 141). Se o consolo de doces Lucrécias é o seu quinhão habitual, Leiris reconhece que um cotidiano anódino requer um "dilaceramento moral", “um santo terror", atributos das Judites. Ocorre, porém, de Judite e Lucrécia serem "verso e reverso da mesma medalha” (Leiris, 2003, p. 133). As duas faces do eterno feminino, "vistas apenas sob o ângulo do sangue derramado" (Leiris, 2003, p. 142), preservam na ambigüidade as forças contraditórias do terror e da piedade. Está claro que um particular erotismo se deixa reconhecer nessa ambigüidade. Através dele, o auto-retratista procura se resgatar da estereotipia, da banalidade e da impassibilidade de seus objetos desejados. Castração, suicídio, culpabilidade, narcisismo, relações angustiantes entre a volúpia e a morte: toda uma sugestividade emerge, com o auxílio do ecfrástico, de alegorias que guardam em sua duplicidade a força de subverter os canônicos espelhos das Virtudes e dos Vícios.

Leiris confessa-se seduzido à obsessão pelas alegorias,
12 Cumpre convir que a éctrase tendo por função "deixar ver" um objeto ausente através $d$ texto escrito, prescinde de qualquer acompanhamento ilustrativo. Ela é iá illustratio no sentido em que é figura de representação como ima gem na escrita. Abstemo-nos, pois, aqui, de fornecer as reproduções das pinturas de Cranach descritas por Leiris. Aliás, se lembrarmos - com Louis Marin (1993, p. 73) - como o aparato descritivo permite que $o$ ausente retorn na leitura na forma de presença fantasmática, imaginária, talvez enhamos uma pista para explcar por que os editores de l'Âg d'Homme não se entendem quanto às ilustrações a adotar De fato, a versão de Dresde do díptico de Cranach, versão a que o texto se refere, não fo usada na primeira edição de 1939, mas somente em 1946 quando L'Âged'Hommefoi precedido pelo ensaio introdutório "De la littérature Considéré Comme une Tauromachie". Na edição de bolso de 1966, díptico cede lugar ao torso de Judite segurando o que parec ser sua própria cabeça. Na edição folio de 1973, as pinturas de Cranach simplesmente desaparecem para dar luga à figura semi-abstrata de uma Judite-dama-de-copas. Aedição brasileira, por fim, é ricamente ilustrada pelas versões do díp tico de Cranach pertencentes a coleções de Viena, Budapeste, Bamberg e Houston Estranhamente, diga-se, uma vez que Leiris não faz menção a nenhuma delas. No fim da contas, as imagens de idolatria de Leiris não acabariam por assombrar seu texto, impor-the seus poderes próprios? 
" $[. .$.$] ao mesmo tempo lições pela imagem$ e enigmas a resolver, em geral atraentes figuras femininas em plena força de sua própria beleza e de tudo o que um símbolo, por definição, tem de perturbador [...]. O gosto que tenho pelo hermetismo procede em grande parte do mesmo movimento que esse amor antigo pelas 'alegorias', e estou convencido de que devo igualmente aproximar desse último o meu hábito de pensar por fórmulas, analogias, imagens - técnica mental da qual o presente escrito, queira eu ou não, é apenas uma aplicação" (Leiris, 2003, pp. 53-4).

É o erudito, dândi das letras, que aqui se confessa transido pela capacidade de transfiguração do alegórico; sobre tal modelo ele procura edificar seus lugares de memória. Monumentos, bustos, mosaicos, baixos-relevos: todo vestígio do antigo se presta ao arqueólogo de si para produzir sua galeria dos desejos e temores. O que movimenta, aliás, sua escrita é a imitação do gesto infantil de folhear compêndios como o Nouveau Larousse Illustré em busca de voluptuosas imagens antigas e de ensinamentos sobre os mistérios da sexualidade, pilar de toda personalidade. Quando criança, Leiris descobrira em manuais escolares o antigo como uma ocasião de volúpia, que o escritor adulto esforça-se para reviver. Escusas imagens ancestrais são emprestadas de verbetes sobre Cranach, Judite e Lucrécia, entre outros. Toda uma galeria de imagens "fortes" e "salientes", como diria Cícero -na verdade, imagens estereotipadas de um fundo cultural -, alimentada pelas inúmeras écfrases do texto, procura reconstituir, ainda que fantasiosamente, o erotismo de uma Antigüidade que reúne sensualidade e suicídio na mesma chave de uma fatal e sibilante "sinuosidade": "torção do corpo prestes a cair" e "sinuosidade da lâmina" associadas (Leiris, 2003, p. 32). Jogos de linguagem são postos assim a desatar os nós das palavras, ricamente entrelaçadas na infância dos espantos e das perturbações.

Sonhos são nós tão intrincados quanto as palavras, e não escapa ao terapeuta de si obcecado por analogias o fato de a escrita ser, mais que simples meio de reproduzir um sonho, "a última fase do trabalho de sonho" (Lejeune, 1996, p. 258). Donde a procura por submeter o onírico ao mesmo processo de decomposição e recomposição que Leiris impõe às palavras fascinantes de sua infância. Anotando-os judiciosamente, "emendando-os uns nos outros", os sonhos surtem "pequenos romances” (Leiris, 2003, p. 177). Espaços diminutos de formulação plena, onde "penetrar à força os mistérios" (Leiris, 2003, p. 177)? Ou elementos de fachada de um "abrigo inviolável" onde impera o trompe-l'oeil (Leiris, 2003, p. 165)? Um começo de resposta talvez esteja na interpretação de Lejeune para esses "pequenos romances":

“[...] desenvolvimento e encadeamento dos fantasmas por meio de jogos de palavra e jogos de estilo; tudo se passa como se os sonhos não mais fossem materiais a reunir brutos, mas pontos de partida de um novo devaneio, bastante consciente e sempre dirigido, que continua o trabalho de sonho desenvolvendo sistematicamente fantasmas e símbolos e apagando-lhes talvez todo o anedótico” (Lejeune, 1996, p. 260).

Em suma, trabalho de mitologização onírica.

Não temos neste breve texto como investigar a pertinência da interpretação de Lejeune. Não é, porém, sem interesse ressaltar o "estado de despojamento" de que em dado momento se ressente Leiris. Impossibilitado de forjar mitos para si, e "aspirando ardentemente à sinceridade", ele não vê contradição em se postar uma vez mais “diante daqueles pólos legendários aos quais [...] nos referimos sempre, porque só eles permitem viver" (Leiris, 2003, p. 147). Ou porque só eles permitem narrar? Significativamente, Leiris endereça-se a uma mulher-ídolo, síntese das duas imagens obsedantes de Lucrécia e Judite: imagem última, de fortuna, pois que depositário de todas as demais, por força de seu particular estatuto de destinatária de toda a enunciação. "Por força de seu afastamento, ela se confunde com minha nostalgia, insinua-se entre 
mim e a maior parte de meus pensamentos" (Leiris, 2003, p. 147). Eis a instância veraz da escrita: o $e u$ se confunde com o ele da morte soberana e lhe cede a palavra. A imagem última não é mais que

"[...] substância de melancolia, imagem de tudo o que nos falta, isto é, de tudo o que desejo e que me atém a essa necessidade urgente de me exprimir, de formular em frases mais ou menos convincentes o sempre demasiado pouco que ressinto, e de fixá-lo num papel penetrado que sou pela idéia que uma musa é necessariamente uma morta, uma inacessível ou uma ausente..." (Leiris, 2003, p. 148).

A escrita parece por fim obsedada por um irredutível vazio, pelo que se abre na lucidez como um "incomensurável abismo" (Leiris, 2003, p. 148). Intervalo que se abre, como um dilema, entre o mundo real, "que me domina e me devora (como Judite) pelo sofrimento e pelo medo", e o mundo dos fantasmas, "que se dissolve entre minhas mãos, que destruo (como Lucrécia apunhalada) sem jamais chegar a possuí-lo" (Leiris, 2003, p. 187). Quanto às écfrases, elas se prestam a escancarar esse abismo, escavar, alimentar quiçá o gozo (moralmente desimpedido) do literato-arqueólogo em preenchê-lo. De todo modo, ao transformar sua imagem mais "insolente" em imagem de uma morta, de uma inacessível, de uma ausente, o texto dá a impressão uma vez mais de aspirar à escrita de um presente que apenas se revela na antecipação de seu desaparecimento. A presença de Leiris em A Idade Viril parece definitivamente carregar, em torno do pescoço, o laço que faz parte da família dos garrotes. Laço torcido em nó, laço do supliciado. De todo modo, adorno funesto. A bem da verdade, Lucrécia e Judite são signos de uma beleza "ardente e triste", como diria Baudelaire, beleza que lhes vem de uma fragilidade desesperadora, malgrado a monumentalidade que assumem suas aparições. Enfim, seu efeito de presença (inequivocamente fantasmática) cativa pelo futuro que não contém.

A "galeria de lembranças" prometida inicialmente para "liquidar" com o que oprime e compromete o futuro do autor - e que um tratamento psicológico deixara sem solução - faz valer, através do descritivo, o gênero epidítico do discurso. Isto é, ela propõe expor virtudes e vícios daquele que corporifica o mais vivamente possível a passagem dramática "do caos miraculoso da infância à ordem feroz da virilidade" (Leiris, 2003, p. 40). Ao fazê-lo, ela demonstra que o auto-retrato resulta sobretudo de um compromisso entre o mais geral e o mais particular. Lugares da Mitologia e da História são ali reinvestidos e reinventados, o sacro e o profano encontram via comum. Não surpreende, pois, que, na galeria labiríntica e voluptuosa da licenciosidade antiga, imagens alegóricas "petrificadas" nos manuais venham cruzar com todo um "teatro de lubricidades ocultas" (Leiris, 2003, p. 59, tradução modificada). Afinal de contas, criaturas "perturbadoras" como Lucrécia e Judite surgem unicamente em função de um "desvio" do museu, do antigo, da cultura humanista. É como se o auto-retratado precisasse passar por uma Antigüidade a um tempo solene e devassa, desejável e brutal, para retornar a si, e transformar seus topoi em lugares de uma paradoxal dissolução redentora. Inevitavelmente, à solenidade do antigo responde seu lado Messalina, sedutor desvio da tópica escolar que permite aproximar o museu e o bordel. Leiris pode, então, ajuizar:

"Nada me parece assemelhar-se tanto a um bordel quanto um museu. Há nele o mesmo lado suspeito e o mesmo lado petrificado. Num, as Vênus, as Judites, as Suzanas, as Junos, as Lucrécias, as Salomés e outras heroínas, em belas imagens fixadas; no outro, as mulheres vivas, vestidas com seus enfeites tradicionais, com seus gestos, suas locuções, seus hábitos inteiramente estereotipados. Em ambos os lugares se está, de certa maneira, sob o signo da arqueologia; e, se durante muito tempo apreciei o bordel, é porque ele também participa da Antigüidade, em razão de seu caráter de mercado de escravos, prostituição ritual" (Leiris, 2003, p. 60). 
A analogia, lembra Michel Beaujour (1980, p. 219), parecerá paradoxal apenas para quem esquece que o auto-retrato é por natureza uma prática furtiva, e privilegia a subversão das enciclopédias oficiais para fins de enredo particular. Desvelados pelo teatro do livro, corpus amplamente descritivo, imagens ressoantes sugerem que cada qual pode tirar seu gozo particular do que é ancestral e primitivo. Nesse sentido, afirma Beaujour (1980, p. 209), “a comunicabilidade do auto-retrato depende tanto da universalidade dos tópicos quanto da generalidade do fantasma". O arqueólogo de si tira sua volúpia - e seu sofrimento
- desse imaginário dividido entre o universo humanista das referências culturais e os fantasmas do gozo íntimo. Em lugar de ser um instrumento de normalização, a cultura oferece-lhe a chance de inventar uma diferença - que, alternadamente, ele exalta e dela padece.

Assim, percorrer o ecfrástico em A Idade Viril é se aperceber de um instrumental maior de transferência de clichês culturais, que fechariam o texto e seu autor num enquadramento harmonioso se a violência de uma escrita exorbitada, libidinosa, não os abrisse para a morte soberana e suas cortesãs licenciosas.

\section{BIBLIOGRAFIA}

BARTHES, Roland. Roland Barthes por Roland Barthes. Trad. Leyla Perrone-Moisés. São Paulo, Estação Liberdade, 2003. BEAUJOUR, Michel. Miroirs d'Encre. Rhétorique de l'Autoportrait. Paris, Seuil, 1980.

HOLLIER, Denis. "Le Déséquilibriste", in Critique, 1981, pp. 189-99.

JACQUES, Francis. Différence et Subjectivité. Paris, Aubier-Montaigne, 1982.

LEIRIS, Michel. L'Âge d'Homme. Précédé de De la Littérature Considérée comme une Tauromachie. Paris, Gallimard, 1946. Fibrilles. Paris, Gallimard, 1966. . Biffures. Paris, Gallimard, 1975. Frêle Bruit. Paris, Gallimard, 1976. Le Ruban au cou d'Olympia. Paris, Gallimard, 1981. Journal. 1922-1989. Paris, Gallimard, 1992. A Idade Viril. Precedido por Da Literatura como Tauromaquia. Trad. Paulo Neves. São Paulo, Cosac \& Naîf, 2003. LEJEUNE, Philippe. Le Pacte Autobiographique. Paris, Seuil, 1996.

MARIN, Louis. Des Pouvoirs de I'Image. Paris, Seuil, 1993. 

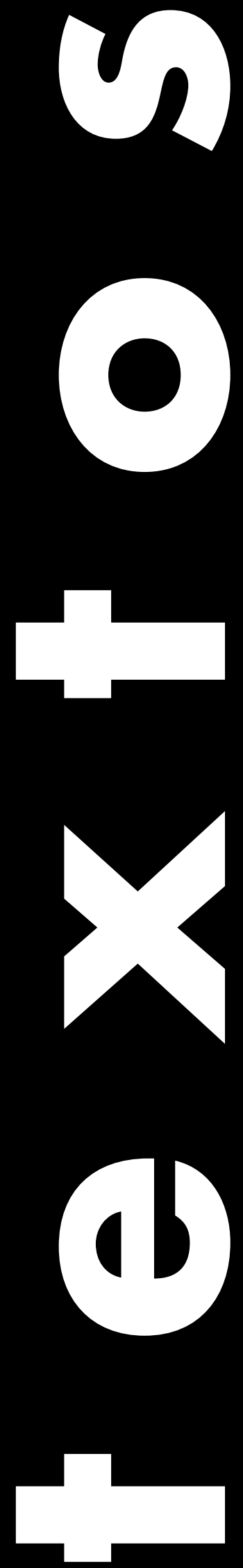